\title{
Mixing Characteristics of Gas-Liquid Flow in a Static Mixer: a Numerical Study
}

\author{
Ryan Anugrah Putra \\ Department of Mechanical \& Industrial Engineering, Faculty of Engineering, Universitas Gadjah Mada \\ Email: ryan.putra@ugm.ac.id
}

Received: March 20 , 2020; Accepted : June 19, 2020; Published : November 1, 2020

\begin{abstract}
Mixing characteristics of gas-liquid co-current upward flow inside a vertical pipe equipped with a helical static mixer element were numerically investigated. The results from computational fluid dynamics (CFD) simulations with EulerEuler model of three different length to diameter ratio (L/D) of the static mixer elements were compared. All simulated static mixers provide a better mixing condition in the comparison with the one without a static element. The sudden increase of rotational strength indicated by the liquid velocity curl was observed once the gas-liquid flows enter the staticmixer element zone. The smallest L/D static mixer provides the highest liquid velocity curl in the smallest axial distance providing the most effective mixing process among the tested elements. The best mixing characteristics shown by radial gas distribution was achieved with the static mixer with a smallest L/D.
\end{abstract}

Keyword: Static mixer; Swirling flow; CFD; Gas-liquid flow; Euler-Euler.

\section{ABSTRAK}

Karakteristik pencampuran aliran gas dan cairan yang mengalir searah ke atas di dalam pipa vertikal yang dilengkai dengan static mixer diteliti secara numerik. Perbandingan dilakukan terhadap hasil dari simulasi komputasi fluida dinamika (CFD) dengan model Euler-Euler untuk tiga static mixer yang memiliki rasio antara panjang dan diameter (L/D) yang berbeda. Semua static mixer yang diuji pada studi ini memberikan kondisi pencampuran yang lebih baik dibandingkan dengan pipa yang tidak dilengkapi dengan static mixer. Kenaikan kekuatan putaran yang diindikasikan oleh velocity curl dari cairan dapat diamati dari hasil simulasi pada lokasi dimana aliran gas-cairan memasuki zona di dalam static mixer. Velocity curl cairan tertinggi diperoleh dengan menggunakan static mixer yang memiliki L/D terkecil pada jarak aksial terkecil yang memberikan proses pencampuran yang paling efektif diantara static mixer yang diuji pada penelitian ini. Karakteristik pencampuran terbaik yang ditunjukkan oleh distribusi gas radial diperoleh dengan menggunakan static mixer dengan L/D terkecil.

Kata Kunci : Static mixer; aliran berputar; CFD; aliran gas-cairan; Euler-Euler.

\section{INTRODUCTION}

Mixing is an important process in many applications e.g. chemical, bio-chemical, pharmaceutical, agricultural and food industries [1][2]. Increasing the interfacial area between phases to enhance mass and heat transfer is one of the important objectives of the mixing process in multi-phase systems e.g. bubble column, air lift loop reactors and pipes [1][3]. The inline mixer using a static mixer element offers advantage as it is more compact and can be done inside the pipe facilities thus reducing the equipment cost and space [4]. However, mixing of liquid and gas which have a large density difference is a challenging process. The studies of gas-liquid mixing inside the static mixer either experimental or numerical is still limited [3-5]

As pointed out by [4][6], the static mixer in some conditions may act as a separator instead of a mixer as shown in the experiment of [4][7] which both using a helical static mixer inside a pipe. Using advance measurement technique of ultrafast electron beam X-ray tomography[4] observed that the centrifugal force generated by the static mixer element leads to the formation of a swirling flow where the gas is accumulated towards the center of the pipe while the liquid towards the pipe wall. They also observed that the addition of static mixer elements reduces the swirling motion of the gas-liquid flows[4].

To enhance the knowledge on the important factors (e.g. operating conditions e.g. liquid and/ or gas velocities, the swirl element geometry, fluid properties, etc.) which influence significantly the mixing characteristics of the gas-liquid flow inside the static mixer, more studies are required. Therefore, in this work the investigation on the mixing characteristics of gas-liquid flows inside a helical static mixer was performed. The investigation was focused on the influence of the static mixer geometry/dimension to the 
mixing characteristic. For that purpose, three different length to diameter ratio (L/D) static mixers were numerically analyzed and compared using computational fluid dynamics (CFD). The comparison to the pipe without a static mixer was also carried out to demonstrate the benefit of the static mixer.

\section{METHOD}

The computational domain for the CFD study is shown in Figure 1a. The domain is the vertical pipe with diameter of $27 \mathrm{~mm}$ and length of $500 \mathrm{~mm}$. The static mixer (see Figure $1 \mathrm{~b}$ ) is placed at the axial distance of $100 \mathrm{~mm}$ from the inlet. Three different static mixers were used in this study. All of them has the same diameter (i.e. $27 \mathrm{~mm}$ ) but differs in the length or the length to diameter ratio (L/D). Static mixer 1 (SM 1), static mixer 2 (SM 2) and static mixer 3 (SM 3) have the length of $50 \mathrm{~mm}(\mathrm{~L} / \mathrm{D}=1.9), 100 \mathrm{~mm}(\mathrm{~L} / \mathrm{D}=3.7)$ and $200 \mathrm{~mm}(\mathrm{~L} / \mathrm{D}=7.4)$, respectively. For the comparison purpose, the CFD simulation was also performed for the condition of the pipe without static mixer which further named as "pipe". The mixing characteristic inside the static mixer was assessed by observing the gas distribution on several cross-sectional area or planes shown in Figure 1a. As an addition, the gas distribution on the axial central plane was also analyzed. The best mixing condition should provide the well distributed gas fraction inside the static mixer.

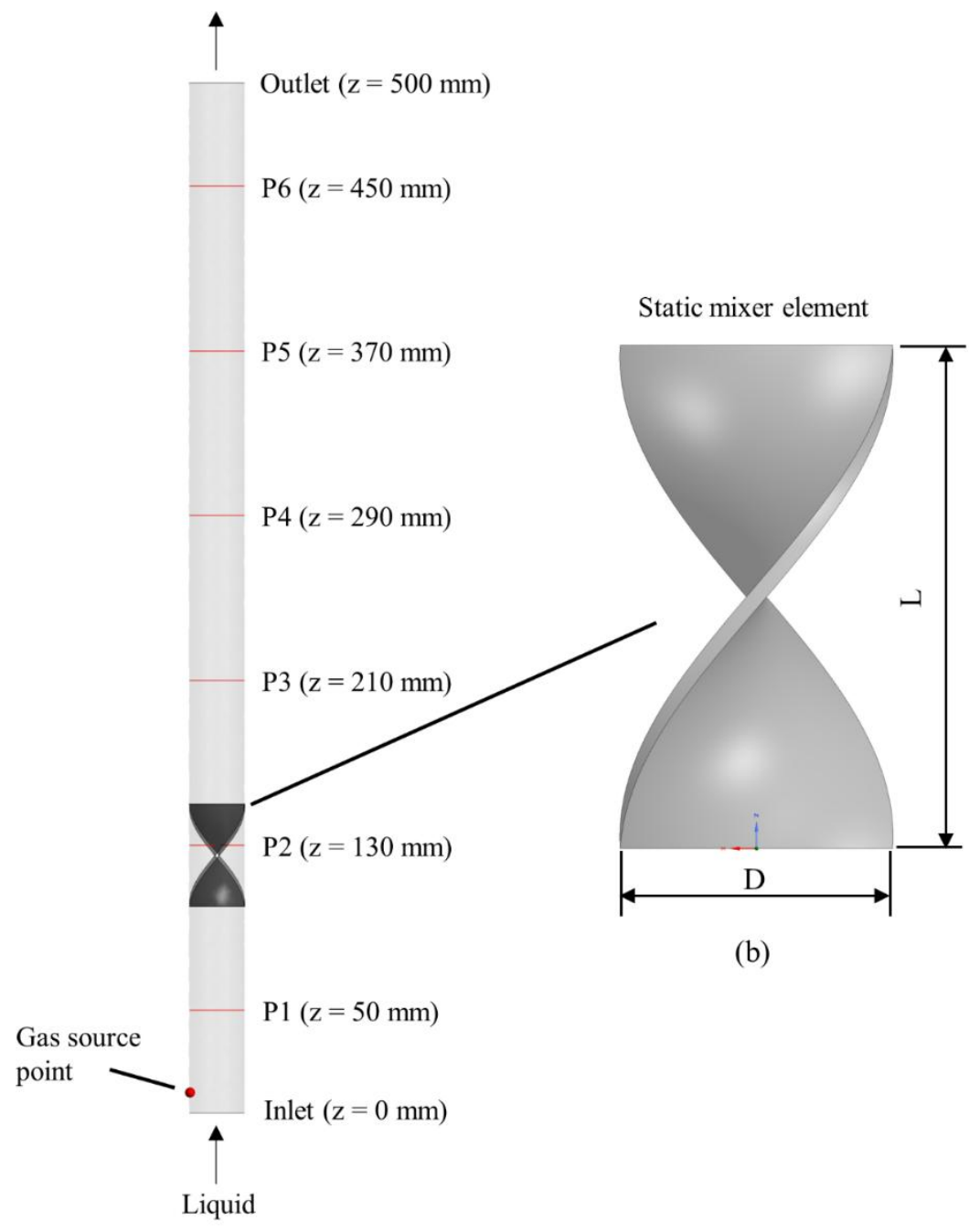

(a)

Figure 1 (a) Computational domain and the measurement planes for calculated gas fraction and (b) static mixer element [4][6][7].

In this study, the CFD simulations were carried out using Euler-Euler model in the fixed computational cells. The liquid is water and defined as continuous phase while the gas is air and defined as mono-dispersed phase with uniform bubble size of $0.5 \mathrm{~mm}$. Two set of continuity and momentum equations 
(i.e. each set for each phase $j$ ) as shown in Eq. 1 and Eq. 2, respectively, are solved in the simulation [8]:

$$
\begin{gathered}
\frac{\partial}{\partial t}\left(\alpha_{j} \rho_{j}\right)+\nabla \cdot\left(\alpha_{j} \rho_{j} \boldsymbol{u}_{j}\right)=S_{j} \\
\frac{\partial}{\partial t}\left(\alpha_{j} \rho_{j} \boldsymbol{u}_{j}\right)+\nabla \cdot\left(\alpha_{j}\left(\rho_{\alpha} \boldsymbol{u}_{j} \times \boldsymbol{u}_{j}\right)\right)=-\alpha_{j} \nabla p+\nabla \cdot\left(\alpha_{j} \mu_{j}\left(\nabla \boldsymbol{u}_{j}+\left(\nabla \boldsymbol{u}_{j}\right)^{T}\right)\right)+\boldsymbol{M}_{j}+S_{M j}
\end{gathered}
$$

where $\alpha_{j}$ and $\rho_{j}$ represent the volume fraction and the density. The velocity vector of phase $j$ is represented by $\boldsymbol{u}_{j}$ [8]. The variables $t, S_{j}$, and $p$ denote the time, mass source, and pressure, respectively [8]. The momentum sources due to external body forces are represented by $S_{M j}$. The interfacial forces $\boldsymbol{M}_{j}$ are the sum of the bubble forces [8]:

$$
\boldsymbol{M}_{j}=\boldsymbol{F}_{\text {drag }}+\boldsymbol{F}_{\text {lift }}+\boldsymbol{F}_{\text {wall }}+\boldsymbol{F}_{T D}+\boldsymbol{F}_{V M}
$$

where $\boldsymbol{F}_{\text {drag }}$ is the drag force and defined according to [9]. The lift force $\boldsymbol{F}_{\text {lift }}$ and the wall lubrication force $\boldsymbol{F}_{\text {wall }}$ were defined according to [10] and [11], respectively. The turbulent dispersion force $\boldsymbol{F}_{T D}$ and the virtual mass force $\boldsymbol{F}_{V M}$ were defined according to [12] and [13]-[15], respectively. For turbulence model of the liquid, the k- $\omega$-based shear stress transport (SST) model proposed by [16] was used in this work. As an addition, the model of [17] was applied to account the turbulence induced by bubbles.

For the boundary conditions, the liquid mass flow rate of $0.114 \mathrm{~kg} / \mathrm{s}$ was defined at the inlet. The gas was introduced into the domain via source point located at the axial distance of $20 \mathrm{~mm}$ from the inlet (see Figure 1a) with the mass flow rate of $1.388 \times 10^{-6} \mathrm{~kg} / \mathrm{s}$. Pressure boundary was defined at the outlet. All other parts were defined as no-slip wall condition. As for the initial conditions, the whole computational domain is filled with water (i.e. without gas) having the axial velocity of $0.2 \mathrm{~m} / \mathrm{s}$ which is equal to the liquid mass flow rate of $0.114 \mathrm{~kg} / \mathrm{s}$. The hydrostatic pressure and the medium turbulence intensity (i.e. $5 \%$ ) were defined throughout the domain.

The CFD simulations were performed using ANSYS CFX 19.2 Student Edition under the steadystate mode. High resolution advection scheme and first order turbulent numeric were used for the solver control. A residual target of $1 \times 10^{-4}$ (RMS) was set as the convergence criteria. As an addition, an almost constant gas hold-up should be achieved at the end of the simulation. For all simulations presented in this study, both convergence criteria were successfully achieved. The mesh for the present study was generated using ANSYS Meshing. For mesh independence study, three different mesh were employed and the volumetric average of gas volume fraction inside the computational domain (i.e. gas hold-up) were used to analyze the mesh influence (see Table 1). Considering the relatively small difference between the gas hold-up obtained by Mesh A and Mesh C (i.e. below $5 \%$ ) and the smallest computational cost, mesh A was used in the present study.

Table 1. Mesh Independence Study

\begin{tabular}{rrrrr}
\hline Mesh & Number of elements & $\begin{array}{c}\text { Gas hold-up } \\
\left(\times 10^{-3}\right)\end{array}$ & \% difference of gas hold-up in comparison to \\
& & 7.37 & 3.7 \\
Mesh A & 32,625 & 7.21 & 1.4 \\
Mesh B & 72,498 & 7.11 & 0 \\
Mesh C & 178,940 & & \\
\hline
\end{tabular}

\section{RESULTS AND DISCUSSION}

Figure 2 shows the contours of gas fraction on the central plane for gas-liquid flow inside the pipe without and with static mixer element. Without static mixer, the gas flows close to the wall along the pipe from the source point to the outlet (see Figure 2a). The poor mixing process leads to inability of the gas to reach the other half part of the pipe. The use of a static mixer promotes a much better mixing condition as can be seen in Figure $2 \mathrm{~b}$-d. The gas is mixed with the liquid inside the static mixer element. In the case of the smallest L/D ratio static mixer (i.e. SM 1) the oscillating gas structures was observed downstream the element (Figure 2b). In the case of SM 2, a significant amount of gas fraction flows closes to the wall of the pipe after some axial distance downstream the element (Figure 2c). In the case of SM 3, a thin layer of gas closes to the wall was still observed after some axial distance downstream the element (Figure 2d). 


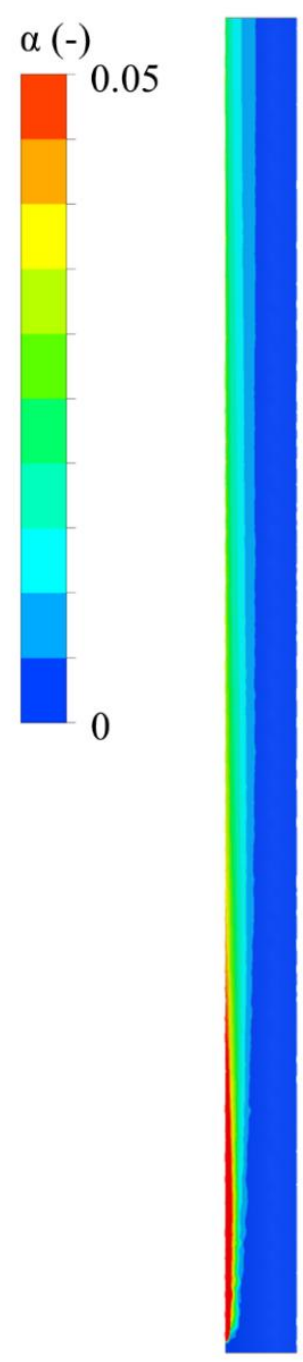

(a)

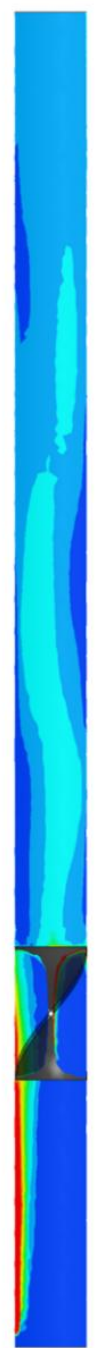

(b)

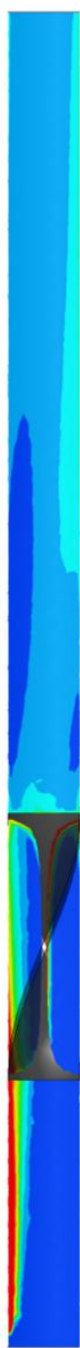

(c)

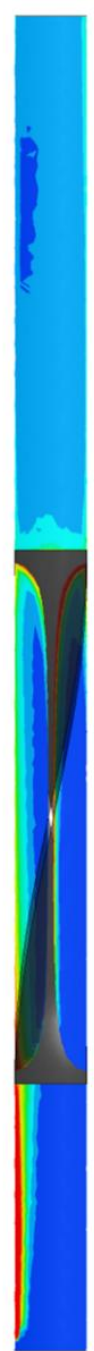

(d)

Figure 2 Contours of calculated gas fraction on the central plane for: (a) pipe, (b) SM 1,

(c) SM 2 and (d) SM 3.

The streamlines of the liquid velocity presented in Figure 3 may explain the axial profiles of gas fraction presented in Figure 2. In the case of without static mixer, no significant change in the streamlines can be observed (Figure 3a). The most significant disruption to the streamlines occurs in the case of SM 1 (Figure $3 b)$. The streamlines are twisted in the region inside the static mixer generating the swirling flow like the one observed in the previous CFD works [5][6]. The difference in the twisting behaviour of the streamlines is observed for different L/D static mixer where the smallest L/D (i.e. SM 1) generates the best swirling flow condition. 


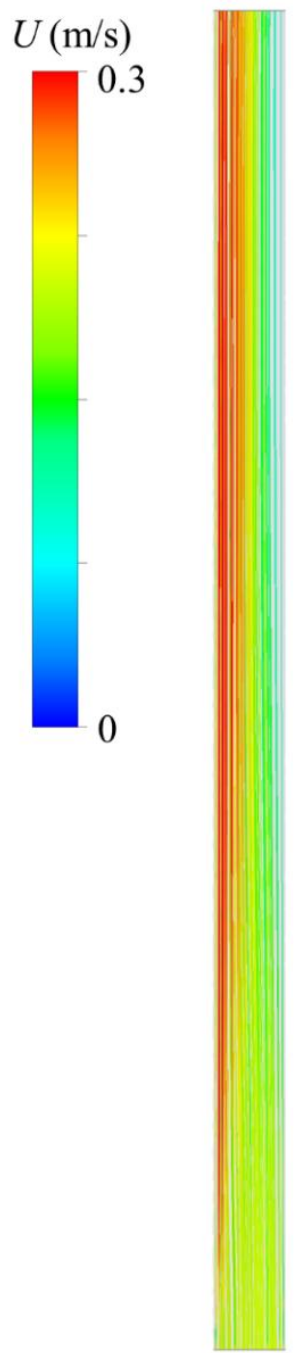

(a)

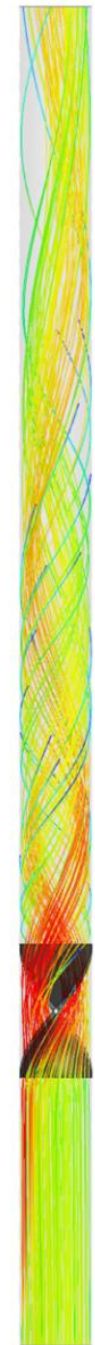

(b)

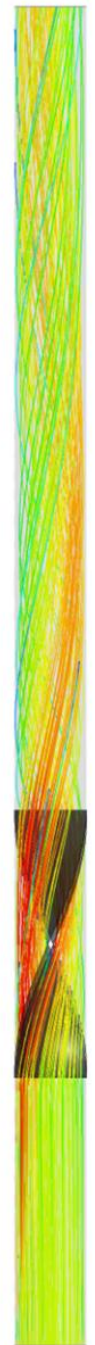

(c)

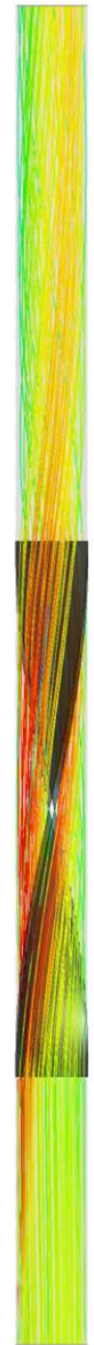

(d)

Figure 3 Streamlines of liquid velocity for simulations of: (a) pipe, (b) SM 1, (c) SM 2 and (d) SM 3.

Figure 4 presents the contours of gas fraction on some measurement planes from the CFD simulations without and with static mixer element. The gas distribution in the measurement plane 1 (i.e. P1) which is located upstream the element show a similar profile for the condition without and with the static mixer. The gas is accumulated only at one side of the pipe. In P2, the location of the gas for the static mixer has been partly distributed following the orientation of the element (Figure $4 \mathrm{~b}-\mathrm{d}$ of P2). In contrast, the gas almost remains at the same location as P1 for the simulation without static mixer (see Figure 4a of P1 and P2). For SM 1 and SM2, the mixture process continues to perform lead to the improved mixture of gas-liquid observed in P3 which is downstream the element (see Figure 4 b-c of P3). In the case of SM 3, measurement planes P3 and P4 are still located inside the static mixer element, thus the distribution of the gas still following the orientation of the element. The distribution of the gas for the pipe without static mixer in P3 until the outlet remains at the similar position (see Figure 4a of P3-P6). In the case of SM 1, the mixing process is continuously progressing in P4 and P5. The best mixing condition for SM 1 is achieved in P6. In P6, the gas is widely distributed over the cross section of the pipe for the case with static mixer (i.e. SM 1, SM2 and SM 3) in contrast to the one obtained in the case without static mixer. 


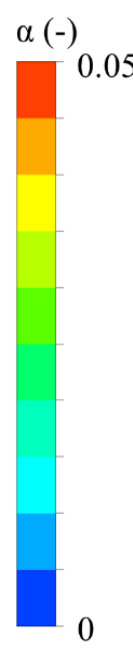

(a)

(b)

(c)

(d)

P6

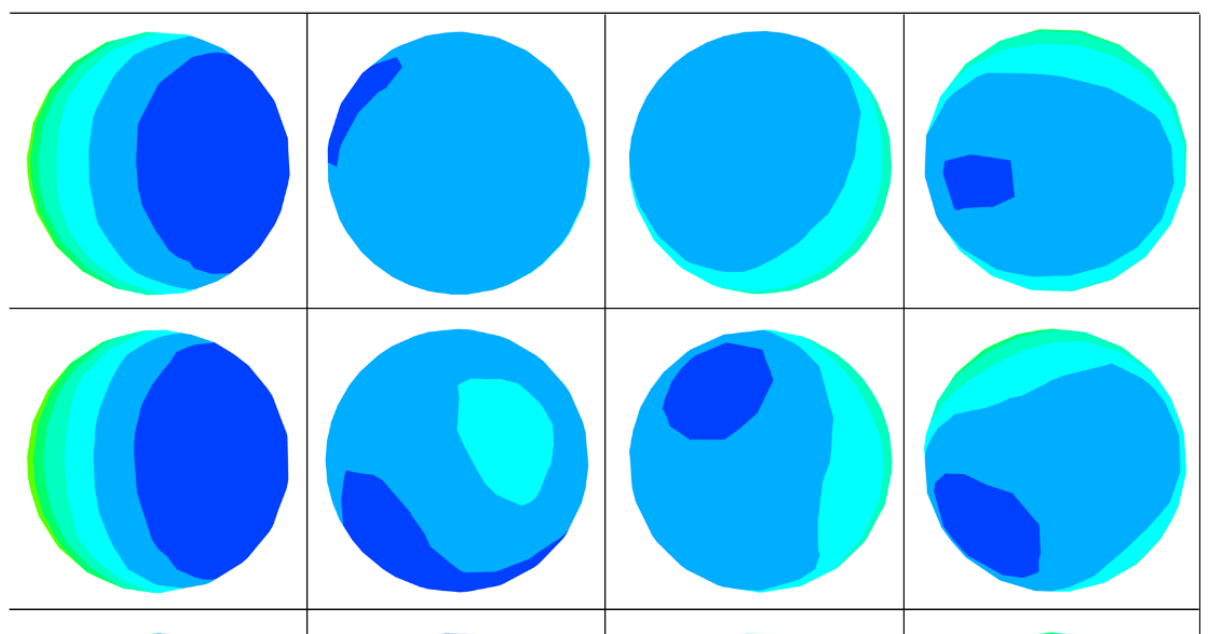

P4

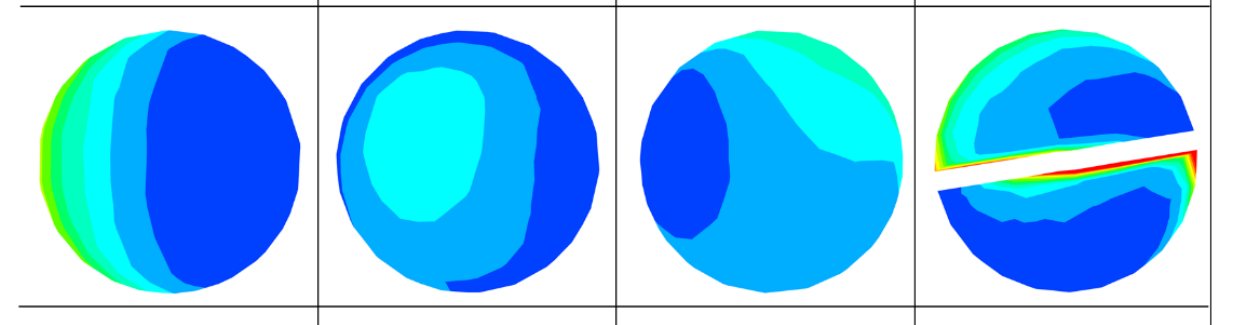

P3

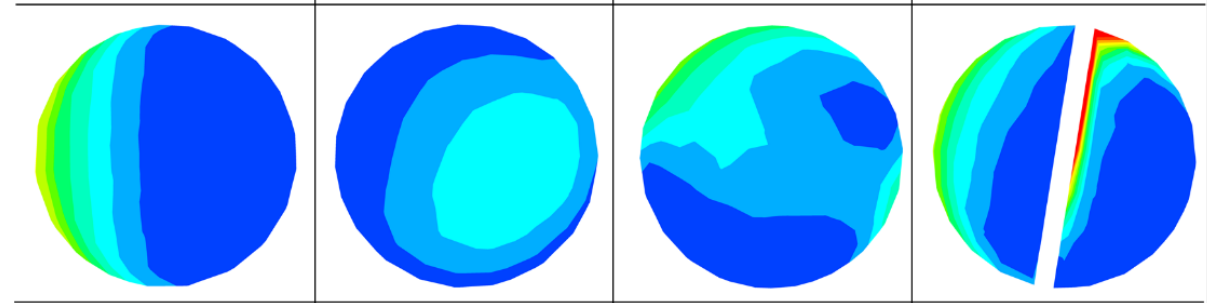

P2

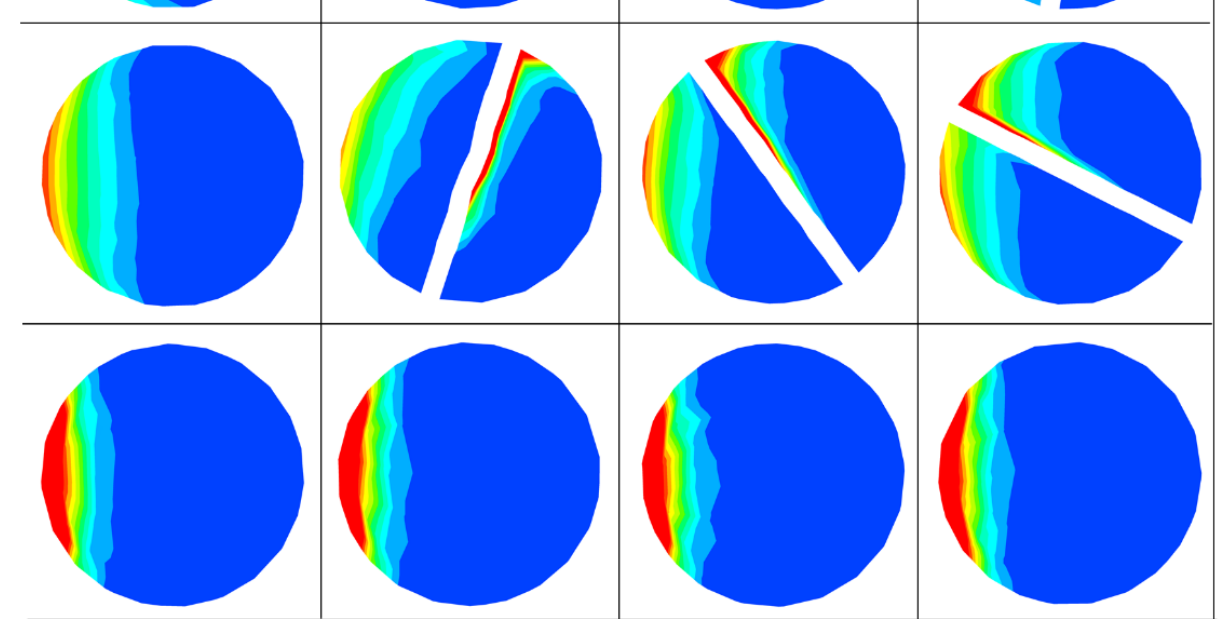

Figure 4 Contours of gas fraction on several measurement planes for simulations of: (a) pipe, (b) SM 1,

(c) SM 2 and (d) SM 3.

To quantitatively compare the gas fraction of the pipe, SM1, SM2 and SM 3, the radial gas distribution profile in P1 and P2 are presented in Figure 5a and 5b, respectively. Figure 5a confirms that the gas distribution for all tested cases is similar in P1 which is located upstream the element. In P6 (Figure 5b), the pipe without static mixer has the worst mixing process. SM 2 and SM 3 provide a better mixing condition than the case without static mixer. However, the wall peak of gas fraction is still observed for the both cases. The best mixing condition is obtained by SM1 since the gas phase is more uniformly distributed on the cross section of P6 as indicated by an almost flat curve shown in Figure 5b. In contrast to SM 2 and SM 3, the wall 
peak of gas fraction disappears in the case of SM 1. To provide possible explanation on this phenomenon, the calculated axial profile of liquid velocity curl indicating the rotational strength is presented in Figure 6 . In the upstream of the element, the velocity curl of the static mixers is similar with the one without static mixer. The profiles largely differ once the gas-liquid flow enters the region inside the static mixer element. The steepest increase of the velocity curl obtained by SM 1 followed by SM 2 and SM 3, respectively. This means that the highest rotational strength is obtained by SM 1 which may explain the reason of best mixing condition achieved by SM 1. As an addition, the maximum value or the peak of the velocity curl of SM 1 is achieved in the shortest axial distance indicating that SM 1 requires the shortest distance to promote the mixing process. As the rotational strength decreased downward the SM 1 element, the gas is more uniformly distributed across the cross sectional are of the pipe as shown in Figure 4a like the observed phenomenon by [4].

(a)

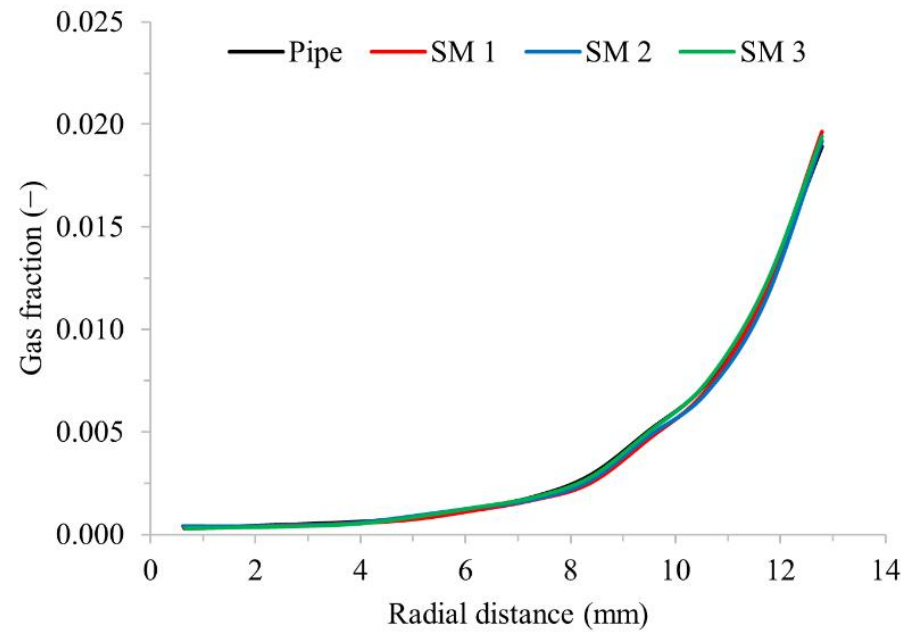

(b)

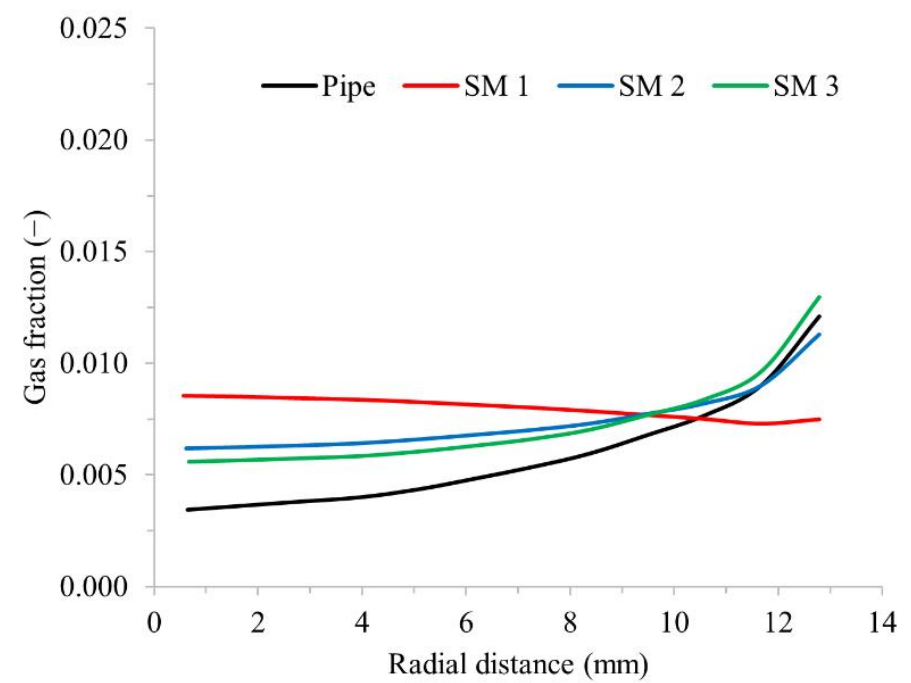

Figure 5 Radial distribution of calculated gas fraction obtained on the measurement planes: (a) P1 and (b) P6. 


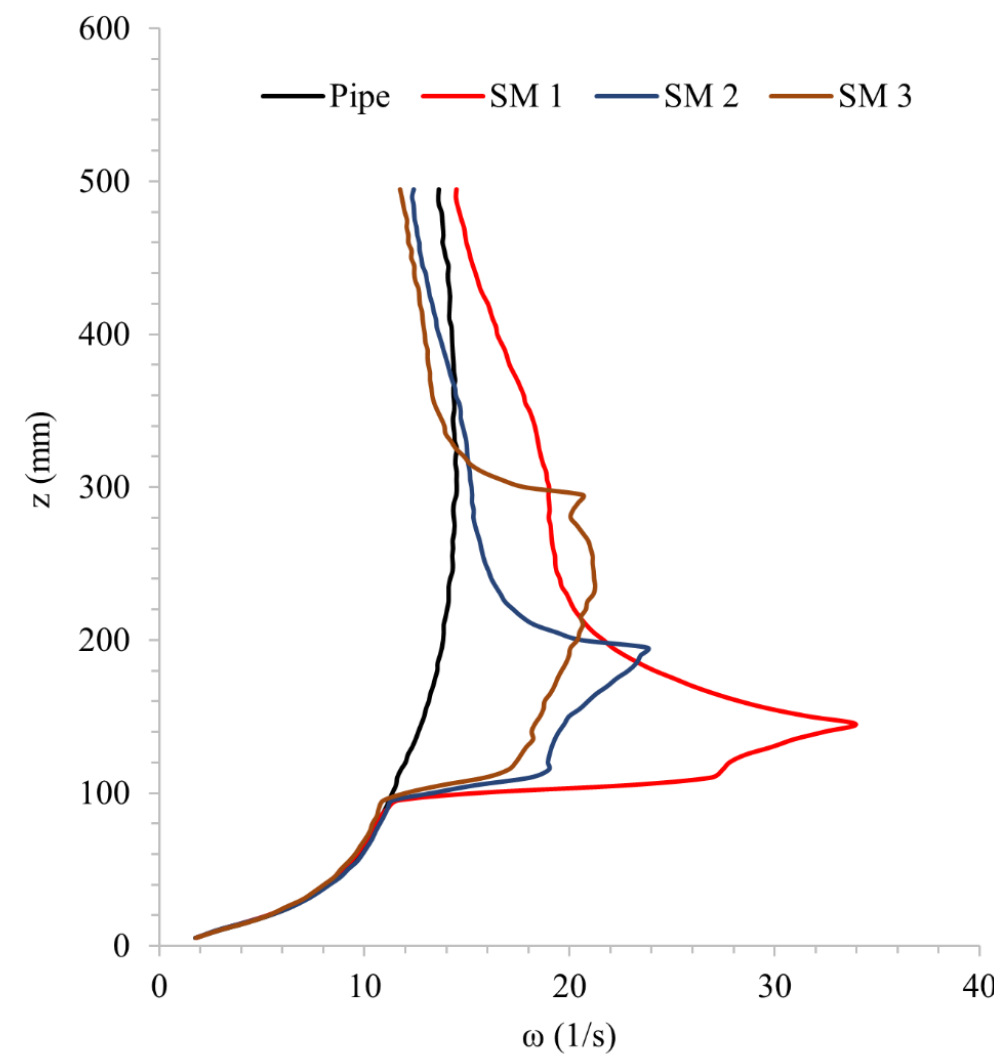

Figure 6 Axial profiles of liquid velocity curl $\omega$ obtained from the CFD simulations of different L/D static mixers and the pipe without static mixer element.

\section{CONCLUSION}

The numerical investigation in this study demonstrates that the mixing process of gas and liquid inside the pipe was significantly improved using helical static mixer. The significant influence of length to diameter ratio (L/D) of the static mixer on the mixing characteristics of gas-liquid flows was observed. The best mixing condition was achieved by the smallest L/D static mixer which has the highest rotational strength providing the most effective mixing process among all tested static mixer in this study. The calculated radial gas distribution profiles show an almost flat curve for the smallest L/D static mixer in the highest measurement plane while other static mixers still show a wall-peak curve.

\section{REFERENCES}

[1] V. Mosorov, "19 - Applications of tomography in reaction engineering (mixing process)," in Industrial Tomography, M. Wang, Ed. Woodhead Publishing, 2015, pp. 509-528.

[2] A. H. Thaker, S. V. Bhujbal, and V. V. Buwa, "Effects of sloshing gas-liquid interface on dynamics of meandering bubble plumes and mixing in a shallow vessel: PIV and PLIF measurements," Chemical Engineering Journal, vol. 386, p. 122036, Apr. 2020, doi: 10.1016/j.cej.2019.122036.

[3] M. Scala, L. Gamet, L.-M. Malbec, and H.-Z. Li, "Hydrodynamics of gas-liquid dispersion in transparent Sulzer static mixers SMXTM," Chemical Engineering Science, vol. 213, p. 115398, Feb. 2020, doi: 10.1016/j.ces.2019.115398.

[4] S. Rabha, M. Schubert, F. Grugel, M. Banowski, and U. Hampel, "Visualization and quantitative analysis of dispersive mixing by a helical static mixer in upward co-current gas-liquid flow," Chemical Engineering Journal, vol. 262, pp. 527-540, Feb. 2015, doi: 10.1016/j.cej.2014.09.019.

[5] F. Zidouni, E. Krepper, R. Rzehak, S. Rabha, M. Schubert, and U. Hampel, "Simulation of gas-liquid flow in a helical static mixer," Chemical Engineering Science, vol. 137, pp. 476-486, Dec. 2015, doi: 10.1016/j.ces.2015.06.052.

[6] R. A. Putra, M. Neumann-Kipping, T. Schäfer, and D. Lucas, "Comparison of Gas-Liquid Flow Characteristics in Geometrically Different Swirl Generating Devices," Energies, vol. 12, no. 24, 2019, doi: $10.3390 /$ en12244653. 
[7] A. Hamdani, T. Ihara, N. Tsuzuki, and H. Kikura, "Experimental study of bubbly swirling flow in a vertical tube using ultrasonic velocity profiler (UVP) and wire mesh sensor (WMS)," Journal of Mechanical Science and Technology, vol. 30, no. 9, pp. 3897-3905, Sep. 2016, doi: 10.1007/s12206016-0801-6.

[8] ANSYS, “ANSYS CFX-Solver Theory Guide, Release 19.2.”2019.

[9] M. Ishii and N. Zuber, "Drag coefficient and relative velocity in bubbly, droplet or particulate flows," AIChE Journal, vol. 25, no. 5, pp. 843-855, Sep. 1979, doi: 10.1002/aic.690250513.

[10] A. Tomiyama, H. Tamai, I. Zun, and S. Hosokawa, "Transverse migration of single bubbles in simple shear flows," Chemical Engineering Science, vol. 57, no. 11, pp. 1849-1858, Jun. 2002, doi: 10.1016/S0009-2509(02)00085-4.

[11] S. P. Antal, R. T. Lahey, and J. E. Flaherty, "Analysis of phase distribution in fully developed laminar bubbly two-phase flow," International Journal of Multiphase Flow, vol. 17, no. 5, pp. 635-652, Sep. 1991, doi: 10.1016/0301-9322(91)90029-3.

[12] A. D. Burns, T. Frank, I. Hamill, and J.-M. Shi, "The Favre Averaged Drag Model for Turbulent Dispersion in Eulerian Multi-Phase Flows," 5th International Conference on Multiphase Flow, ICMF2004, Yokohama, Japan., 2004.

[13] T. R. Auton, J. C. R. Hunt, and M. Prud'Homme, "The force exerted on a body in inviscid unsteady non-uniform rotational flow," Journal of Fluid Mechanics, vol. 197, pp. 241-257, 1988, doi: $10.1017 /$ S0022112088003246.

[14] J. Magnaudet, M. Rivero, and J. Fabre, “Accelerated flows past a rigid sphere or a spherical bubble. Part 1. Steady straining flow," Journal of Fluid Mechanics, vol. 284, pp. 97-135, 1995, doi: $10.1017 /$ S0022112095000280.

[15] M. R. Maxey and J. J. Riley, "Equation of motion for a small rigid sphere in a nonuniform flow," The Physics of Fluids, vol. 26, no. 4, pp. 883-889, Apr. 1983, doi: 10.1063/1.864230.

[16] F. R. Menter, "Two-equation eddy-viscosity turbulence models for engineering applications," AIAA Journal, vol. 32, no. 8, pp. 1598-1605, Aug. 1994, doi: 10.2514/3.12149.

[17] Y. Sato and K. Sekoguchi, "Liquid velocity distribution in two-phase bubble flow," International Journal of Multiphase Flow, vol. 2, no. 1, pp. 79-95, Jun. 1975, doi: 10.1016/0301-9322(75)90030-0. 
